\title{
An Institutional Model for Collaborative Disaster Risk Management in the Southern African Development Community (SADC) Region
}

\author{
Mmaphaka Tau ${ }^{1} \cdot$ Dewald van Niekerk ${ }^{1} \cdot$ Per Becker $^{2}$
}

Published online: 22 December 2016

(c) The Author(s) 2016. This article is published with open access at Springerlink.com

\begin{abstract}
This article presents and argues for a collaborative model for disaster risk management in the Southern African Development Community (SADC). The research employed a qualitative study through a literature review and empirical research through focus group interviews to realize its objectives. As a key theory of multinational collaboration, neoliberal institutionalism-a subset of the international relations theory-was used to develop the SADC institutional collaborative model. The model combined the theoretical, political, and technical dimensions of collaboration to enhance buy-in for the disaster risk management and reduction function of governments. The model demonstrates the need for a multidisciplinary approach to achieving disaster risk management and reduction in the SADC and elsewhere, if the developmental objectives of disaster risk reduction are to be realized without interference in the domestic affairs of the member countries. This model is therefore grounded in seeking consensus and cooperation among cooperating states in a quest to ensure national implementation of the regional framework on disaster risk reduction.
\end{abstract}

Keywords Disaster risk management - Disaster risk reduction - International relations $\cdot$ Neoliberal institutionalism - Southern African Development Community (SADC)

Dewald van Niekerk

dewald.vanniekerk@nwu.ac.za

1 African Centre for Disaster Studies, North-West University, Potchefstroom 2531, South Africa

2 Division of Risk Management and Societal Resilience, Lund University, 22100 Lund, Sweden

\section{Introduction}

The population of the African continent was estimated at 1.033 billion in 2013 and as growing at a rate of $2-4 \%$ per annum (WPR 2015). The growth rate in SADC averaged $2.6 \%$ per annum from 2001 to 2011 with a total population in 2011 of 281 million (SADC 2011). The southern African states do not have a long or rich history of collaboration in terms of disaster risk management (DRM), regardless of common cross-border characteristics of risks and disasters. The absence of a standard collaborative framework that can be employed in the management of risks, as well as for response and recovery from hazards and disasters (for example, fires, epidemics, floods, earthquakes, chemical explosions), provided the impetus for this research. The objective is to present and argue for an institutional model for collaborative DRM in the Southern African Development Community (SADC). Within this context, the article outlines a possible institutional model and working arrangements that can be developed to ensure collaborative DRM in the SADC. The study is motivated by the recognition of the fact that regional systems of DRM are an essential element of global DRM governance, complementing governance efforts at the national and global levels (Van Niekerk 2015). The article is a contribution to enhancing DRM and reduction in the SADC and elsewhere by outlining an institutional model for collaborative DRM within the established international relations theoretical context. This is motivated by the consideration of hazards and disasters, as with development and climate change response, as phenomena that cannot be confined to national boundaries, necessitating the promotion of multinational arrangements for DRM and reduction. It is against this backdrop that the theory of international relations, through 
neoliberal institutionalism, was chosen to provide a theoretical frame of reference.

\section{Disaster Risk Management Through the Lens of International Relations Theory: A Focus on Neoliberal Institutionalism}

The interdependence of international relations with respect to sustainable development, climate change response, and DRM and reduction has been widely documented and implemented, albeit at different levels of maturity (Keohane 1988; SADC 1992; Setear 1997; Sterling-Folker 2000; UNISDR 2005; Dunne et al. 2007; UNFCCC 2007). Since the late 1980s global collective measures have been instituted to refocus and implement DRM and reduction as a concern in the pursuit of sustainable development. The acknowledgment of disasters as the manifestation of unresolved developmental and service delivery problems (Wijkman and Timberlake 1984) and as phenomena that respect no national boundaries have specifically influenced this global drive. Although private companies and civil society have both played important roles in this ongoing endeavor, institutional arrangements for DRM and reduction have mainly been the business of the public sphere in general, and governments in particular. This makes international relations theory central in developing an institutional model for collaborative DRM in the SADC and elsewhere.

For purposes of conceptual grounding, international relations theory refers to theories concerned with the relationships among the world's governments (Goldstein 2004). This theory has relevance to the DRM field due to its focus on diplomatic strategic relations of states, conflict management, general governance, and high-level administrative cooperation (Brown and Ainley 2009), as well as political, economic, and social cross-border transactions (Thornhill 2002; Goldstein 2004; Brown and Ainley 2009). Its subject matter mainly focuses on the relationships between the members of a community such as the SADC. Kennedy-Pipe (2000) adds that the theory and practice of international relations depend (if not fully, then in part) on the regime type and ideological justification for state behavior that shapes the international system. From this line of reasoning, the assumption is made that international relations discourses rely on an understanding of the unique character, interests, and capabilities of members of an international system.

Neoliberal institutionalism contends that, within an international system, states cooperate to achieve absolute gains for their respective national systems (Keohane and Nye 1977; Krasner 1983; Grieco 1993). This cooperation evolves through iterated processes of engagement (Grieco
1993; Setear 1997), and is achieved with the active involvement of international "institutions" or "regimes" as the loci of cooperation in solving the dilemma of collective action (Keohane and Nye 1977; Grieco 1993; Setear 1997; Dunne et al. 2007; Reus-Smit and Snidal 2008) within the international collaborative system.

According to Keohane (1988), Setear (1997), Dunne et al. (2007), and Sterling-Folker (2000), neoliberal institutionalism encompasses theories arguing that international institutions play an important role in coordinating international cooperation. Neoliberal institutionalism further holds the view that multilateralism is more efficient in obtaining collective interests than unilateralism. This is based on the fact that multilateralism derives from the consensus on issues of collective interest, while unilateralism is established on the interests of only one or two parties. In line with this view, Powell (1991) notes that in their pursuit of absolute gains, states holding to neoliberal institutionalism emphasize the prospects for cooperation within the multilateral international system. This line of thinking also convinced the states of the SADC to adopt a Treaty in 1992 that established the SADC as an institution for the purpose of strengthening collaboration between its member countries (SADC 1992, 2004, 2010a). The forming of the SADC has played a key role in allowing cooperation in a multilateral international system. Collaboration on DRM in the SADC is no exception to the focus of the tenets of the neoliberal institutionalism theory: fostering of friendly relations between and among states; states assisting and supporting one another; states informing and consulting one another on matters of common interest; states coordinating (and harmonizing) legislation with one another; and states adhering to agreed procedures and avoiding legal proceedings against each other (OAU 1980; Republic of South Africa 1996; AU 2001, 2004; SADC 2001, 2003; UNISDR 2002; Jackson and Sørensen 2003; Tau 2014).

The principles of neoliberal institutionalism provide a framework within which to conceptualize an institutional collaborative model for DRM in the SADC within the confines of international relations protocols without undermining individual state sovereignty.

\section{Background of the Southern African Development Community (SADC)}

The democratization of the African continent in the 1960s heralded the beginning of a collective vision and structured measures to ensure that Africa prosper in order to meet the needs of its people. This became evident with the emergence of structured policy reforms and greater advocacy for policy alignment to ensure synergies between the 
African states (Holloway 2007). Associated with the liberation and democratization of the African continent, African countries collectively adopted key institutional arrangements and strategic frameworks to govern multinational collaboration on issues relating to the socioeconomic and political development of the continent. Such institutional arrangements include the Organisation of Africa Unity established in 1960 and disbanded in 2002 and replaced by the African Union (AU), and the African Economic Community (AEC) established in 1991 (SADC 2003; AU 2004).

The southern African region has witnessed the establishment of a number of regional cooperation and integration initiatives. Among these are the Southern African Customs Union (SACU-dating back to 1889); the Southern African Development Coordination Conference (SADCC-established in 1980), the forerunner of the SADC; the Indian Ocean Commission (IOC_-established in 1982); the Common Monetary Area (CMA — established in 1986); the Common Market for Eastern and Southern Africa (COMESA - established in 1994), the Indian Ocean Rim Association (IORA-established in 1995); the Eastern Africa Community (EAC_-established in 2000); and also the (SADC-established in 1992) (SADC 2001).

The SADC is a group of 15 member states for the purpose of the development of the southern African region (Shams 2003). The SADC is an interstate economic and political body that aims to achieve development and economic growth, alleviate poverty, enhance the standard and quality of life of the people of southern Africa, and support the socially disadvantaged through regional integration (SADC 2010a). According to Qobo (2007) and Holloway (2007) regionalization in southern Africa was mainly driven by political rather than economic considerations, with trade or economic agendas becoming prominent after the transformation of the SADCC into the SADC in 1992. However, regional cooperation and integration in southern Africa owes its origin to historical, economic, political, social, and cultural factors that have created strong bonds of solidarity and unity among the peoples of the SADC (SADC 2010a; Holloway 2007). These factors have contributed to the formation of a distinct southern African personality and identity that underpins political and economic cooperation.

Regional integration among the southern African countries was first initiated in the 1970s by the Frontline States, which included Angola, Botswana, Mozambique, Tanzania, and Zambia, with the main purpose of achieving political liberalization in the region and the reduction of dependence on apartheid South Africa (Saurombe 2009; Jurčić et al. 2011). However, it was only in 1980 that nine southern African states formed what was then called the SADCC, which reflected the spirit of Pan-Africanism and was focused on the need for regional integration as a means towards the unity of the African continent and the recovery of African dignity and status in global affairs (SADC 2003). Saurombe (2009) indicates that the geopolitical changes during this era included the independence of Namibia from colonial rule (1990), as well as the promise of a new dawn of democracy in South Africa.

With the need for strengthening the SADCC identified, the Windhoek Declaration transformed the SADCC in 1992 to form what is currently known as the (SADC 1992). The redefinition of the SADCC to the SADC changed the organization from a loose association of states towards more legally binding arrangements (Saurombe 2009). The SADC's legal status is outlined in Article 3(1) of the Declaration, which states that the "SADC shall be an international organisation and shall have legal personality with capacity and power to enter into contract, acquire, own or dispose of movable or immovable property and to sue and to be sued" (SADC 1992). The SADC subregion is defined as the total geographical area occupied by the 15 member states of the SADC (Chishakwe 2010). The member states are Angola, Botswana, Democratic Republic of Congo, Lesotho, Madagascar, Malawi, Mauritius, Mozambique, Namibia, Seychelles, South Africa, Swaziland, Tanzania, Zambia, and Zimbabwe.

While the SADC, when compared to Asia and Latin America, is seldom viewed as vulnerable to natural threats, the subcontinent shows increasing patterns of social, economic, and environmental vulnerability (SADC 2010b). Holloway (2007) further noted that during the 2000s the region has experienced recurrent droughts and increasing incidences of flash flooding. Rapid urban and peri-urban growth, progressive land degradation, the impact of HIV/ AIDS, and rising patterns of socioeconomic vulnerability have also brought about sweeping changes to the region's risk profile. It is with the above background that this research aimed to develop an institutional model for collaborative DRM in the SADC region. This was undertaken by employing a qualitative research design.

\section{Methodology}

Qualitative methods in the form of literature study, review of documents, and focus group interviews were utilized (De Vos et al. 2011; Creswell 2003; Henning et al. 2004). The literature study entailed the review of various documents such as government reports, international and SADC declarations, protocols, policy frameworks, discussion documents, books, academic theses, and project reports. The focus group interviews involved the interactive engagement with groups of preselected participants (knowledgeable individuals working with the SADC on a 
national and regional scale). These participants were drawn from disaster management offices of a number of SADC member states, academic institutions involved in disaster risk reduction education, training, and research, state and non-state entities within the SADC, as well as international organizations involved in DRM and reduction and related responsibilities. Participants were selected on the basis of their knowledge and ability to contribute to the research. No participants were excluded due to race, ethnicity, gender, or language difference. All interviews were conducted in English and an even distribution between male and female participants was pursued. In total, seven of the SADC states (Botswana, Lesotho, Malawi, Mauritius, South Africa, Swaziland, and Tanzania), as well as the SADC disaster risk reduction (DRR) Unit and non-state entities (universities and civil society organizations) participated in the research. The focus group interviews were attended by a minimum of five to a maximum of 15 participants and held in the various countries. This participation profile also applied during engagement with non-state entities such as the SADC DRR Unit, academic institutions, and other entities. The remaining eight countries did not participate, either because of logistical or bureaucratic difficulties (inability or lack of permission to travel to and attend the focus group interviews). This emphasizes the need for better collaboration among the SADC states. An integrative analysis approach as suggested by Tesch (1990) was followed to ensure that the various themes involved in the study were clearly described, that the links and relations between the themes were established, and that emerging patterns were identified. The key themes under discussion were drawn from the information gathering directive presented to the SADC member state DRR focal units by the research team. Themes also originated from the focus group interviews and independently from some of the SADC member states and other stakeholders.

\section{Findings}

The findings are presented according to the identified thematic areas to demonstrate how they contributed to arriving at the institutional collaborative model for the SADC.

\subsection{Theme 1: Disaster Risk Management and Reduction as a Function Requiring Collaboration}

The research found that the majority of the respondents felt that improved collaboration between states regarding DRM and reduction is necessary and long overdue. Responses were based on the previous experiences of the respondents in terms of DRR as well as disaster response and recovery.
Each SADC government has to a greater or lesser extent established DRM units in their administration. The collaboration between these units, however, is limited to national foreign interests (for example, assisting each other in disaster response), and does not necessarily extend to day-to-day DRM activities.

\subsection{Theme 2: Reasons for collaboration}

Respondents were given the opportunity to indicate reasons for cooperation based on their experiences of bilateral and regional collaboration. Respondents felt that some national policies and legislation already provide for collaboration. Examples include Namibia (Republic of Namibia 2009, 2011, 2012), South Africa (Republic of South Africa 2003, 2005) and Swaziland (Kingdom of Swaziland 2006). Existing SADC, AU, and UN DRR frameworks encourage collaboration (SADC 2001, 2006, 2010; AU and UNISDR 2004; UNISDR 2005). Because disasters know no boundaries collaboration is an international relations concern. Respondents felt that collaboration will stimulate support and encouragement and provide a platform for sharing expertise with others in the SADC. Collaboration will further facilitate standardization of DRM and reduction policy and implementation frameworks of member states. Better collaboration in DRR will make it easier to support existing bilateral and multilateral collaborative mechanisms within sectors, and programs with an effect on DRR such as fire management, water management, forestry, and the environment. Respondents believed that collaboration will enhance the regional integration and growth called for in the SADC Treaty (SADC 1992, 2001). It will enable the member states to learn from other international collaborative systems such as the Association of Southeast Asian Nations (ASEAN), and the New Zealand Fire Management system. Most importantly, there are already communities along international borders in the SADC region who are involved in collaboration on socioeconomic aspects of their lives.

\subsection{Theme 3: Existing Statutory and Policy Regulations}

A number of countries do have policy and legislative and practical measures for institutionalizing disaster risk reduction. But it became apparent that countries are at different stages in the development of policies and frameworks, though many countries are taking policy and practical steps to deal with disaster risk reduction. Participants acknowledged the need to ensure that DRM and reduction legislation is supported through operational sector legislation and pointed out the need to take stock of sector legislation and policies that contribute to disaster risk 
reduction. This will be critical to ensure balanced implementation of the coordination function and the sector risk management and reduction responsibilities.

\subsection{Theme 4: Bilateral and Multilateral Collaboration}

The need for collaboration across different levels of governance and administration was raised. Given the need for local and national ownership of collaboration, the study explored the perceptions and feelings of the participants on bilateral and multilateral collaboration. There was a general consensus among the participants that bilateral and multilateral collaboration is needed in disaster risk reduction. This implies that participants view collaboration as an essential element of a successful risk reduction system. Participants emphasized the need to use existing mechanisms to achieve DRR objectives and not to reinvent parallel structures to the existing SADC structures.

\subsection{Theme 5: International Support for Collaboration}

The general feeling of the participants was that international institutions should support states in pursuing their collaborative objectives. Due to its mandate on regional integration, the SADC has the responsibility to play the main role in leading and supporting DRR collaboration. Respondents emphasized that international organizations must aim to facilitate collaboration-not to force it. One SADC respondent noted that: "some international organizations use their support as a means to secure funding for their own programs." This is seen to be problematic as it defeats the mutual benefit principle of collaboration. The need for self-awareness and self-actualization was raised. Respondents felt that collaborating partners among the SADC member states must first recognize the need for collaboration within the SADC before outsiders are approached for assistance. Therefore, a better understanding of the role of the different parties and their contribution to DRM and reduction is critical. It is important that natural, human, and financial resources are identified and allocated proactively to address needs and priorities. Participants analyzed and categorized a number of benefits that could flow from the support of international organizations:

- To increase coordination, cooperation, and standardization;

- To promote capacity building, technical expertise, funding support, and advocacy;

- To broker harmonious collaboration between and among member states;
- To support the mobilization of international resources;

- To raise the profile of important work or lessons learned globally; and

- To provide guidance on how collaboration can be achieved.

The view was also expressed that considering such support was subject to the need:

- To clarify the interest of international organizations and accountability lines;

- To look at the risks associated with collaboration;

- For an organized SADC that determines what it needs-not an SADC that acts on external offers; and

- To support international institutions based on need and mutual benefit.

These perspectives show that international organizations and other non-state actors are considered to be critical in supporting DRM discourses in the SADC. This role, however, should occur within the context of SADC needs and priorities and should be aligned with SADC accountability processes. Within that regulated arrangement, the SADC could benefit from the contribution of international organizations and non-state actors.

\subsection{Theme 6: Collaborative Arrangements as Facilitated by the SADC DRR Unit}

The views of the participants were varied, reflecting different levels of understanding about the SADC DRR unit, as well as varied perceptions about its functions and impact on the SADC DRR system. Of concern is the fact that the majority of the non-state agencies involved in DRM and reduction did not know about the unit. Some member state respondents also did not have insight into the unit and its functions. This reflects the need to improve national knowledge sharing of the DRM and reduction systems that are already in place globally. Knowledge should also be improved on the structure of these systems to support national and global efforts.

Another view was that the SADC DRR unit is nonfunctional. Areas for improvement that need to be considered to enable better performance punctuated the discussions on the functioning of the unit. These discussions revolved around organizational structuring, leadership, and administrative considerations. Respondents indicated that there is a need to improve political buy-in for the unit. The unit should be separated from the Organ for Politics, Defence and Security $\left(\operatorname{Organ}^{1}\right)$ and be a stand-alone

\footnotetext{
${ }_{1}$ The Organ for Politics, Defence and Security (Organ) was launched in June 1996 as a formal institution of SADC with the mandate to support the achievement and maintenance of security and the rule of law in the SADC region. The Organ is responsible for coordinating
} 
directorate with its own protocol. The SADC member states need to take full ownership of and allocate resources for the funding of the unit. This must also include secondment of personnel for defined periods to support programs of the unit. Respondents highlighted the need to update and operationalize the SADC DRR strategy. The need for regular coordinating meetings and protocols on dealing with international assistance was mentioned and also the need to improve the collaboration between and among SADC sectors. Participants felt that the success of the collaborative system under the SADC is contingent on the adoption of clear measuring tools in the form of performance indicators. There was consensus that the performance indicators should be aligned with the priorities of the Hyogo Framework for Action 2005-2015 (HFA) (and now the Sendai Framework for Action 2015-2030) (UNISDR 2005, 2015), the Africa Regional Strategy for Disaster Reduction 2004 (AU and UNISDR 2004), and the draft SADC Policy and Strategic Framework for DRR 2010-2015 (SADC 2010a). This alignment must be grounded in national policy and legislation and should consider aspects of climate change and variability. There was also the view that the future framework needs to adopt a tripartite form to address development, disaster risk reduction, and climate change as part of a collective whole.

\subsection{Theme 7: Performance Indicators}

The proposed performance indicators identified by the respondents, which conform to the provisions of the HFA (and also the Sendai Framework), are presented in Table 1.

\section{Overview of the Southern African Development Community (SADC) Institutional Collaborative Model}

The SADC institutional collaborative model for DRM assumes a three-tier structure (represented by A, B, and C in Fig. 1) that includes the AU, the SADC, and the 15 SADC member state perspectives. The successful operation of the model is dependent on internal (SADC) and external (AU and SADC member states) configuration and alignment. An additional external factor of the model is the role of international institutions, state and non-state institutions in facilitating and supporting the collaborative system as represented by the box marked B9 in the figure. The successful implementation of the model is dependent

Footnote 1 continued

SADC actions relating to military/defence, crime prevention, intelligence, peace-making and peacekeeping enforcement, foreign policy, conflict management, prevention and resolution, and human rights. on the effectiveness of the member states' DRR systems, as well as structured and functional SADC DRM and reduction structures (forums), supported by the AU and non-state mechanisms. The effectiveness of the SADC model can influence the effective functioning of the $\mathrm{AU}$ and the SADC member states' DRM systems and vice versa.

\section{Discussion}

As an important measure for successful DRM governance, the SADC institutional collaborative model combines the political (executive leadership) and technical (administrative leadership) components of the SADC DRM structural configuration-based on the principles of neoliberal institutionalism. It was also formulated with due regard to the current configuration within the SADC secretariat. The model used the existing SADC structure as its premise, while also proposing modifications to the existing configuration to ensure the seamless implementation of the SADC DRM collaborative model.

To aid in interpreting the model, the structural components are made up of four elements:

(1) Solid lines show structural and reporting relationships;

(2) Dashed lines show regional relationships within the collaborative system;

(3) Solid lines without arrows show functional relationships; and

(4) Double lines show focal areas associated with a particular function (functional focal areas).

The prominent elements of the collaborative model for DRM in the SADC and the AU, SADC, and SADC member states configuration of the model are clarified below.

Labels A, B, and $\mathrm{C}$ show the AU, SADC, and SADC member states configuration respectively, and how the interfaces give rise to the SADC institutional collaborative model for disaster risk management. The three tiers are connected through the dashed line that shows the regional relationships, a key component of international relations theory. The interface points of the three tiers are reflected by the connecting points of the dashed arrowed line. Boxes A1 to A4 show the institutional hierarchy within the AU system. This culminates with the functional description of the AU DRR system in Box AA that represents multinational projects that are conducted within the AU DRM and reduction system in line with the AU DRR framework.

The SADC configuration is shown in two perspectives represented by boxes $\mathrm{B} 1$ to $\mathrm{B} 10$, and $\mathrm{BA}$ to $\mathrm{BK}$. Boxes B1 to $\mathrm{B} 10$ represent the institutional hierarchy and reporting relationships within the hierarchical structure. Boxes BA to 
Table 1 Performance indicators for the institutional collaborative model for disaster risk management in the Southern African Development Community (SADC). Source Tau (2014, p. 287)

\begin{tabular}{|c|c|}
\hline Performance indicators & Measures \\
\hline $\begin{array}{l}\text { Indicator 1: Formalize SADC DRM political } \\
\text { forums (for example, SADC ministerial } \\
\text { committee on DRR) }\end{array}$ & $\begin{array}{l}\text { Conduct study on political support of SADC DRR } \\
\text { program; present report, with recommendations } \\
\text { to SADC Council of Ministers }\end{array}$ \\
\hline $\begin{array}{l}\text { Indicator 2: Conduct regular technical and } \\
\text { intergovernmental meetings on DRM (for } \\
\text { example, SADC DRR technical committee) }\end{array}$ & $\begin{array}{l}\text { Develop a schedule of meetings (at least } 3 \text { per } \\
\text { year); rotate meetings in SADC member states }\end{array}$ \\
\hline $\begin{array}{l}\text { Indicator 3: Support the formalization of UN } \\
\text { agencies, state and non-state actor forums on } \\
\text { disaster risk reduction (forums may be separated } \\
\text { or one forum can be formed) }\end{array}$ & $\begin{array}{l}\text { Undertake an audit of UN agencies, state and non- } \\
\text { state entities and their DRM mandate and } \\
\text { capacities; establish a forum of international } \\
\text { organizations and non-state agencies; establish } \\
\text { SADC joint DRR technical committee }\end{array}$ \\
\hline $\begin{array}{l}\text { Indicator 4: Give legal status and ratify SADC } \\
\text { policy and other implementation frameworks }\end{array}$ & $\begin{array}{l}\text { Audit all existing frameworks and identify gaps; } \\
\text { improve and adopt frameworks; formulate and } \\
\text { ratify a stand-alone SADC protocol on DRM/R } \\
\text { and its supporting declaration; ratify SADC } \\
\text { policy and strategic frameworks for DRR } \\
\text { (prioritize pre-and-post disaster phases); } \\
\text { undertake and audit memorandum of } \\
\text { understanding (MoU) and other frameworks } \\
\text { required to support DRR in SADC; adopt MoU } \\
\text { Protocol for SADC (with bilateral and } \\
\text { multinational focus) }\end{array}$ \\
\hline
\end{tabular}

Indicator 5: Promote SADC disaster risk reduction unit to a directorate

Indicator 6: Develop a database on regional and national DRM/R capacity and resources

Indicator 7: Formulate and adopt a SADC capacity development, research, and communications framework

Indicator 8: Formulate and adopt the International Disaster Response Laws, Rules and Principles (IDRL) guidelines for SADC to ensure coordinated institutional coordination

Indicator 9: Establish a stand-alone DRR budget for SADC with clear funding protocols

Indicator 10: Formalize relationships with existing sectoral collaborative forums (for example, joint bilateral commission on cooperation, and so on)
Assess and address human resources capacity development for SADC DRR Directorate; revise SADC secretariat structure and factor in climate change function and responsibilities; adopt DRR policy and resources plan

Undertake an audit of DRM needs in the region; compile an audit of national DRM capacities; compile an audit of national DRM capacities and resources

Undertake DRM capacity building needs analysis for SADC; undertake DRM capacity building resources analysis for SADC; undertake DRM research needs and resources analysis for SADC; develop and ratify SADC DRM capacity building framework and communications protocols

Based on an audit of needs and resources in SADC adopt guidelines and implementation plans

Conduct an audit of SADC DRM funding needs and potential sources; develop and funding framework and guidelines; establish and operationalize SADC DRM funding

Conduct and audit existing sectoral forums; identify collaborative areas; develop collaborative instruments between DRM institutional systems and sector collaborative systems
Responsible agent

SADC secretariat supported by UN agencies and member states

SADC secretariat supported by member states

SADC secretariat, UNISDR with the support of member states

SADC secretariat with support of agencies and member states

Member states under the coordination of the Council of Ministers (facilitated by SADC secretariat)

Member states under the coordination of SADC secretariat

SADC secretariat supported by member states

SADC secretariat working with member states, other agencies and under full political support

SADC secretariat working with member states, other agencies and under full political support

SADC secretariat working with member states, other agencies and under full political support
BK represent the functional descriptions associated with the institutional boxes (B1 to B10). The summit of the Heads of State to the SADC joint DRM Task Team (boxes $\mathrm{B} 1$ to B10) represent structures within the SADC system, while boxes BA to BK explain the nature of those structures and what the different administrative levels are responsible for. For the institutional model for collaborative DRM in the SADC, the SADC DRR Inter-Ministerial 


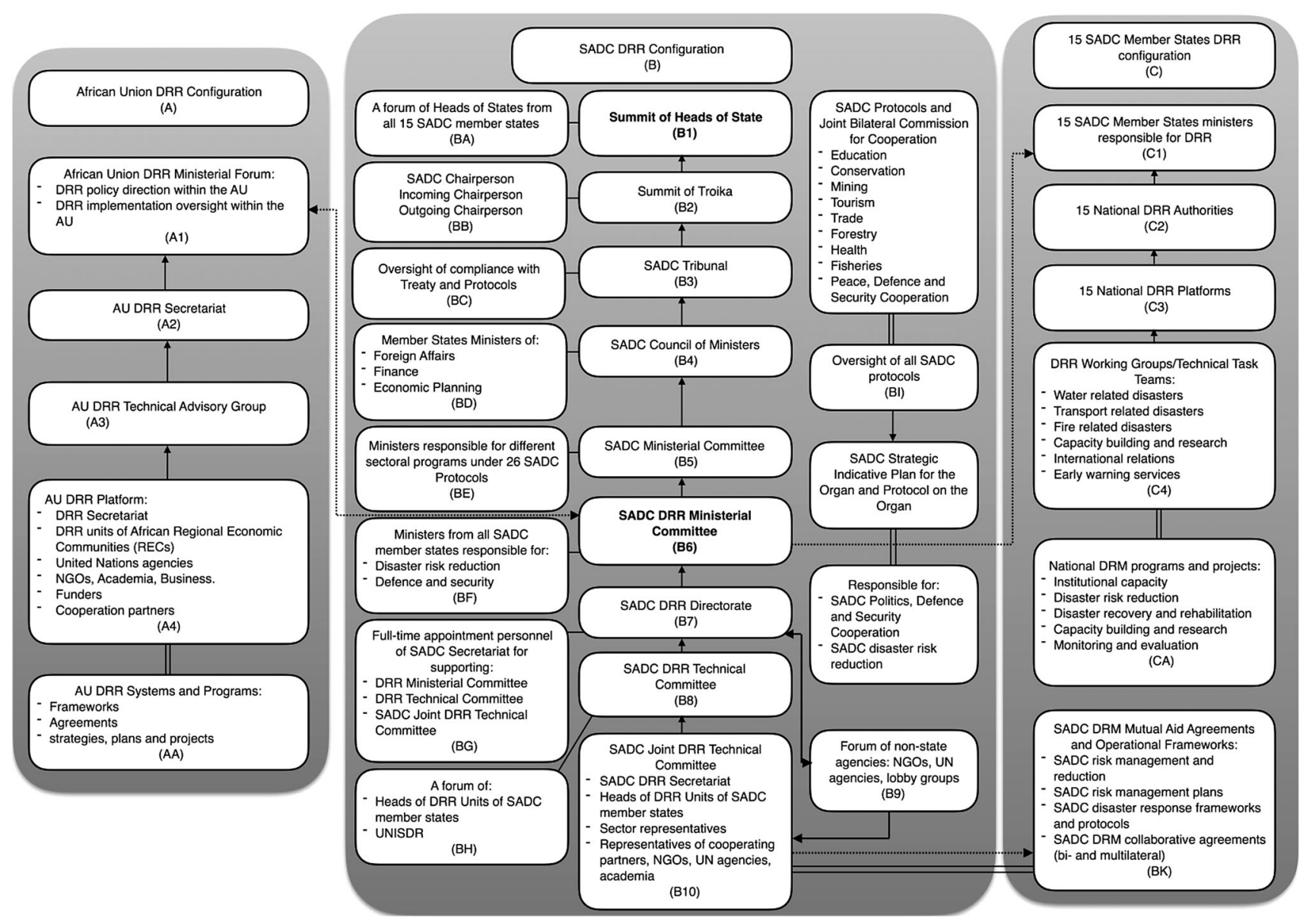

Fig. 1 The Southern African Development Community (SADC) institutional collaborative model for disaster risk management. Source Authors

Committee (B6) is critical because it provides political direction and stewardship for DRM and reduction in the SADC and is aligned with the theoretical grounding of neoliberal institutionalism of diplomatic strategic relations of states, conflict management, and general governance. Through the work of the SADC DRR Inter-Ministerial Committee (B6) and that of its subordinate structures such as the SADC DRR Directorate (B7), the SADC DRR Technical Committee (B8), the Forum of non-state agencies (B9), and the Joint DRR Technical Committee of the SADC (B10), the actualization of the institutional collaborative model is conducted through SADC DRM Mutual Aid Agreements and Operational Frameworks (Box BK). This implies that the functioning of the administrative units represented in these boxes (B6, B7, B8, B9, and B10) will culminate in the SADC collaborative system as shown in box BK (addressing high-level administrative cooperation, as well as all manner of political, economic, and social cross-border transactions). The arrow and double line linking the SADC Joint DRR Technical Committee (B10) and the SADC DRM Mutual Aid Agreements and Operational Frameworks (BK) show (1) the functions to be performed by the Joint DRR Technical Committee (B10); and the fact that the mutual aid agreements and operational frameworks will assume a bilateral and multilateral form and represent regional relationships.

Within the SADC system, the success of the collaborative model hinges on the existence and functioning of the Summit of Heads of State (B1), the SADC DRR InterMinisterial Committee (B6), the Forum of non-state agencies (B9), and the SADC Joint DRR Technical Committee (B10). The need for a forum of non-state agencies and the joint technical task team (boxes B9 and B10) confirms that neoliberal institutionalism dictates theory and practice of international relations in DRM and reduction.

As with any other program, the success in the implementation of the model hinges on the identification of strategic measures necessary to make the collaborative system effective. Those measures must revolve around policy frameworks, institutional review, and the national (member states) and the SADC's adoption of performance indicators against which to measure the success of the model. These measures are not in place currently within the SADC system, hence the ineffectiveness of the system as 
expressed by a number of the respondents. Flowing from the empirical and theoretical study, the performance indicators have been devised to guide the implementation of the model.

The SADC model must be structured in such a way that it enhances the DRM and reduction objectives of the SADC in line with its developmental objectives. The model must also be aligned with regional (AU), global (UN), and national (SADC member states) systems and priorities. To this end, performance indicators that underscore the successful implementation of the SADC institutional collaborative model were identified from the information obtained through the theoretical and empirical perspectives of the research. The performance indicators relating to political, technical, and systemic issues are combined in Table 1 as a separation is not necessary due to their interdependence based on the theory of international relations discussed above. Responsibilities for actualizing each of the measures of the collaborative model are assigned to the relevant agents or entities within the region.

The performance indicators for the SADC institutional model for collaborative DRM represent a menu of strategic activities to be undertaken to ensure the effectiveness of collaboration in the region. This collaboration will be made possible, vertically and horizontally, through the involvement and structured support of international organizations and other state and non-state actors (see boxes B8, B9, and B10). The key feature of the model is that state ownership of the collaborative effort is crucial, with support from international institutions (Keohane 1988; SADC 1992; Setear 1997; UNISDR 2005). The model proves that neoliberal institutionalism, albeit not in its totality, is a relevant theory to explain and design an institutional model for collaborative DRM in the SADC and elsewhere. The cases of the Association of Southeast Asian Nations' (ASEAN) regional collaboration on DRM and on environmental governance lend credence to this model and the argumentation presented in this article (ASEAN 1997, 2005; Singh 2008).

\section{Conclusion}

The research revealed that the current institutional arrangements and processes within the SADC need to be enhanced. It also showed that, while the role of the state is central in fostering collaboration, international institutions and other non-state actors have a crucial role to play in supporting international collaboration among states as postulated through neoliberal institutionalism. International collaboration should take place within two perspectives: bilateral and multinational collaboration based on clearly defined interests and collaborative objectives.
The research shows that collaboration should first be needs-driven, fit for purpose, and owned by the collaborating states, and that the role of international organizations must be supportive in nature. This model can be applied to structure supranational collaboration on disaster risk reduction. The congruence of the literature on the subject and the agreement of the empirical data are an indication that the SADC institutional model for collaborative DRM is critical to enhancing the current SADC disaster risk management and reduction system.

Open Access This article is distributed under the terms of the Creative Commons Attribution 4.0 International License (http://creative commons.org/licenses/by/4.0/), which permits unrestricted use, distribution, and reproduction in any medium, provided you give appropriate credit to the original author(s) and the source, provide a link to the Creative Commons license, and indicate if changes were made.

\section{References}

ASEAN (Association of Southeast Asian Nations). 1997. Vision 2020. Kuala Lumpur: ASEAN.

ASEAN (Association of Southeast Asian Nations). 2005. Agreement on disaster management and emergency response. Vietiane: ASEAN.

AU (African Union). 2001. New partnership for Africa's development. Addis Ababa: AU.

AU (African Union). 2004. Africa regional strategy for disaster risk reduction. Draft for discussion at the meeting of experts, 31 May-1 June 2004. Johannesburg, South Africa.

AU and UNISDR (African Union and United Nations International Strategy for Disaster Reduction). 2004. Africa regional strategy for disaster risk reduction: Disaster risk reduction for sustainable development in Africa. Addis Ababa: AU.

Brown, C., and K. Ainley. 2009. Understanding international relations. New York: Palgrave Macmillan.

Chishakwe, N.E. 2010. Southern Africa sub-regional framework on climate change programmes report. http://www.unep.org/roa/ amcen/docs/AMCEN_Events/climate-change/southAfrica/ SADC_Report.pdf. Accessed 17 Sept 2015.

Creswell, J. 2003. Research design: Qualitative, quantitative and mixed methods approaches, 2nd edn. Thousand Oaks: Sage.

De Vos, A.S., H. Strydom, C.B. Fouche, and C.S.L. Delport. 2011. Research at grass roots: For the social and human services profession, 4th edn. Pretoria: Van Schaik.

Dunne, T., M. Kurki, and S. Smith. 2007. International relations theories: Discipline and diversity. New York: Oxford University Press.

Goldstein, J.S. 2004. International relations, 5th edn. Washington DC: Longman.

Grieco, J.M. 1993. Anarchy and the limits of cooperation: A realist critique of the newest liberal institutionalism, neorealism and neoliberalism. New York: Columbia University Press.

Henning, E., E. Van Rensburg, and B. Smith. 2004. Finding your way in qualitative research. Pretoria: Van Schaik.

Holloway, A. 2007. Drought emergency, yes...drought disaster, no: Southern Africa 1991-93. Cambridge Review of International Affairs 14(1): 254-276.

Jackson, R., and G. Sørensen. 2003. Introduction to international relations: Theories and approaches. New York: Oxford University Press. 
Jurčić, L., V. Bilas, and F. Sanja. 2011. Regional economic integration and developing countries: The example of South African regional integration-SADC. In Proceedings of 8th International Conference Economic Integration, Competition and Cooperation, 6-9 April 2011, University of Rijeka, Opatija, Croatia.

Kennedy-Pipe, C. 2000. International history and international relations theory: A dialogue beyond the cold war. International Affairs 76(4): 741-754.

Keohane, R.O. 1988. International institutions: Two approaches. International Studies Quarterly 32(4): 379-396.

Keohane, R.O., and J.S. Nye. 1977. Power and interdependence: World politics in transition. Boston: Little Brown.

Kingdom of Swaziland. 2006. Disaster Management Act 2006. Mbabane: Government Printers.

Krasner, S.D. 1983. International regimes. Ithaca, NY: Cornwell University Press.

OAU (Organisation of African Unity). 1980. Lagos plan of action for the economic development of Africa. Addis Ababa: OAU.

Powell, R. 1991. Absolute and relative gains in international relations theory. The American Political Science Review 85(4): 1303-1320.

Qobo, M. 2007. The challenges of regional integration in Africa: In the context of globalisation and the prospects for a United States of Africa. Institute for Security Studies Paper 145. https://www. issafrica.org/research/papers/the-challenges-of-regional-integra tion-in-africa-in-the-context-of-globalisation-and-the-prospectsfor-a-united-states-of-africa. Accessed 13 Dec 2016.

Republic of Namibia. 2009. National Disaster Risk Management Policy. Windhoek, Namibia.

Republic of Namibia. 2011. National Disaster Risk Management Plan. Windhoek, Namibia.

Republic of Namibia. 2012. Disaster Risk Management Act. Windhoek: Government Printers.

Republic of South Africa. 1996. The Constitution of the Republic of South Africa Act 108 of 1996. Pretoria: Government Printer.

Republic of South Africa. 2003. Disaster Management Act No. 57 of 2002. Pretoria: Government Printer.

Republic of South Africa. 2005. National Disaster Management Framework 2005. Pretoria: Government Printer.

Reus-Smit, C., and D. Snidal. 2008. The Oxford handbook of international relations. Oxford: Oxford University Press.

SADC (Southern African Development Community). 1992. Treaty of the Southern Africa development community. Gaborone: SADC Secretariat.

SADC (Southern African Development Community). 2001. SADC multi-sectoral disaster risk management strategy. Gaborone: SADC

SADC (Southern African Development Community). 2003. Regional indicative strategic development plan. Gaborone: SADC Secretariat.

SADC (Southern African Development Community). 2004. SADC regional strategic indicative development plan for the Organ. Gaborone: SADC Secretariat.

SADC (Southern African Development Community). 2006. SADC disaster risk reduction strategic plan. Gaborone: SADC.

SADC (Southern African Development Community). 2010a. SADC policy and strategic framework for disaster risk reduction 2010-2015. Gaborone: SADC.
SADC (Southern African Development Community). 2010b. Report in the SADC Disaster Risk Reduction and Preparedness Planning Workshop. 5-8 October 2010, Gaborone, Botswana. http:// reliefweb.int/sites/reliefweb.int/files/resources/Full_report_101. pdf. Accessed 13 Dec 2016.

SADC (Southern African Development Community). 2011. SADC statistics yearbook 2011. Gaborone: SADC. http://www.sadc.int/ information-services/sadc-statistics/sadc-statiyearbook/\#Popula tion. Accessed 13 Dec 2016.

Saurombe, A. 2009. SADC trade agenda, a tool to facilitate regional commercial law: An analysis. South African Mercantile Law Journal 21(5): 695-709.

Setear, J.K. 1997. Law in the service of politics: Moving neo-liberal institutionalism from metaphor to theory by using the international treaty process to define "Iteration". Virginia Journal of International Law Association 37. http://faculty.virginia.edu/ setear/cv/vjil.pdf. Accessed 14 Sept 2015.

Shams, R. 2003. Regional integration in developing countries: Some lessons based on case studies. HWWA Discussion Paper No. 251. https://ssrn.com/abstract $=475781$ or http://dx.doi.org/10. 2139/ssrn.475781. Accessed 9 Aug 2015.

Singh, J.N. 2008. Process of institutionalisation and democratization in ASEAN: Features, challenges and prospects of regionalism in South Asia. UNISCI Discussion Paper No. 16. https://www.ucm. es/data/cont/media/www/pag-72513/UNISCI\%20DP\%2016\% 20-\%20Singh.pdf. Accessed 14 Sept 2015.

Sterling-Folker, J. 2000. Competing paradigms or birds of a feather? Constructivism and neoliberal institutionalism compared. International Studies Quarterly 44(1): 97-119.

Tau, M.E. 2014. An institutional model for disaster risk management in the Southern African Development Community. Doctoral thesis. Potchefstroom: North-West University.

Tesch, R. 1990. Qualitative research: Analysis types and software tools. Oxon: Routledge.

Thornhill, C. 2002. An overview of intergovernmental relations in Africa. South Africa Foundation for Public Management and Development. Pretoria: Van Schaik.

UNFCCC (United Nations Framework Convention on Climate Change). 2007. The Bali Action Plan. Bali, Indonesia: UNFCCC.

UNISDR (United Nations International Strategy for Disaster Reduction). 2002. Living with risk: A global review of disaster reduction initiatives. Geneva: UNISDR.

UNISDR (United Nations International Strategy for Disaster Reduction). 2005. Hyogo framework for action 2005-2015: Building the resilience of nations and communities to disasters. Geneva: UNISDR.

UNISDR (United Nations International Strategy for Disaster Reduction). 2015. Sendai framework for disaster risk reduction 2015 2030. Geneva: UNISDR.

Van Niekerk, D. 2015. Disaster risk governance in Africa: A retrospective assessment of progress in against the Hyogo Framework for Action (2000-2012). Disaster Prevention and Management 24(3): 397-416.

Wijkman, A., and L. Timberlake. 1984. Natural disasters: Acts of god or acts of man? Washington DC: Earthscan.

WPR (World Population Review). 2015. Africa population 2015. http://worldpopulationreview.com/continents/africa-population/. Accessed 14 Feb 2016. 